\title{
Muhasebe Meslek Mensuplarının Haksız Rekabet Algılarının Analitik Hiyerarşi Süreci Yöntemi ile Değerlendirilmesi \\ (Evaluation of Unfair Competition Perceptions on Accounting Professionals by Analytical Hierarchy Process Method)
}

\author{
Gencay KARAKAYA iD a Ali Altuğ BİÇER iD b \\ a İstanbul Ticaret Üniversitesi, İşletme Fakültesi, İstanbul, Türkiye. gkarakaya@ticaret.edu.tr \\ b İstanbul Ticaret Üniversitesi, İşletme Fakültesi, İstanbul, Türkiye. abicer@ticaret.edu.tr
}

\begin{tabular}{l} 
MAKALE BİLGİsi \\
\hline Anahtar Kelimeler: \\
Haksız Rekabet \\
Analitik Hiyerarşi Süreci \\
Muhasebe Meslek Mensupları
\end{tabular}

\section{ÖZET}

Amaç - Finansal ekosistemde küreselleşme ile başlayan hızlı değişim günümüzde dijitalleşme ile işletmelerin giderek daha karmaşık hale gelmesine, bu gelişmeler karşısında müşteri işletmelerin talep ve beklentilerin de hızla değişmesine sebep olmuştur. Süreç içerisinde gerek mevzuat gerekse standartların getirmiş olduğu gereklilikler ve ilave iş yükü, hızla artmakta olan meslek mensubu sayısı ile birlikte değerlendirildiğinde rekabet koşullarının gitgide zorlaştığı görülmektedir. Çalışmanın temel amacı, muhasebe meslek mensuplarının haksız rekabet algılarının ölçülmesidir.

Yöntem - Çalışmada, konusunda uzman meslek mensupları ile yapılan görüşmeler analitik hiyerarşi Gönderilme Tarihi 2 Ocak 2020 yöntemi ile değerlendirilip meslek mensuplarının haksız rekabet algısı ortaya konulmaya çalışılmıştır.

Revizyon Tarihi 20 Nisan 2020 Bulgular - Haksız rekabet muhasebe meslek mensuplarının karşılaştığı birçok sorun arasında ilk sırada Kabul Tarihi 4 Mayıs 2020 yer almaktadır. Meslek mensupları mesleki davranış kurallarına uymuyor ve temel etik ilkelere ve kavramsal çerçeveye aykırı hareket ediyorsa haksız fiile sebep olabilecek davranışlarda bulunabilmektedir. Çalışma kapsamında meslek mensuplarının haksız rekabet algılarına ilişkin alternatifler derecelendirilmiştir.

Makale Kategorisi:

Araştırma Makalesi

Tartışma - Meslek mensupları dürüstlük ilkesi gereği tüm mesleki ilişkilerinde ilgili taraflara karşı açık ve dürüst olmalıdır. Burada geçen dürüstlük ilkesi, haksız rekabet fiili TTK (md.54/2) ve Medeni Kanun (md.2)'da açıkça belirtilmemiş olmasına rağmen dürüstlük noktasında örtüşmektedir. Haksız rekabet hukuki yönüyle farklı çevreleri ilgilendiren çok geniş bir konu olup bu çalışma muhasebe meslek hukuku açısından haksız rekabet fiili ile sınırlandırılmıştır. Bu kapsamda bütüncül bir perspektifte, muhasebe hizmetlerinde haksız rekabetin önlenmesini yönelik çalışmaların yönlendirilmesinde AHP yaklaşımından yararlanılabilir.

\begin{tabular}{l}
\hline ARTICLE INFO \\
\hline Keywords: \\
Unfair Competition \\
Analytical Hierarchy Process \\
Accounting Professionals
\end{tabular}

\section{ABSTRACT}

Purpose - The rapid change that started with globalization in the financial ecosystem has led to the increasing complexity of businesses with digitalization, and the demands and expectations of customer enterprises have changed rapidly in the face of these developments. When the requirements and extra workload brought by both the legislation and the standards are evaluated together with the rapidly increasing number of professionals, it is seen that the competition conditions become increasingly difficult. The main purpose of this study is to measure the perception of unfair competition among professional accountants.

Received 2 January 2020

Revised 20 April 2020

Design/methodology/approach - In this study, the interviews with experts in the field were evaluated by analytical hierarchy process and the perception of unfair competition was tried to be revealed.

Accepted 4 May 2020

Findings - Unfair competition is one of the most important problems faced by professional accountants. If members of the profession do not comply with the rules of professional conduct and act against the code of ethics and conceptual framework, they may act in a manner that may lead to unjust act. Alternatives were graded according to their members' unfair competition perceptions.

Article Classification:

Discussion - Professionals should be straightforward and honest to all interested parties in all their Research Article professional relations in accordance with the principle of integrity. The principle of integrity mentioned here overlaps at the point of honesty, although the act of unfair competition is not explicitly stated in the TCC (art. 54/2) and the Civil Code (art. 2). Unfair competition is a very broad subject that concerns different parties with its legal aspect and this study is limited to the act of unfair competition in terms of accounting profession. In this context, AHP approach can be used in a holistic perspective, in guiding the efforts to prevent unfair competition in accounting services.

\section{Gíriș}


Aynı amacı güden tarafların olduğu bir ortamda çekişme/yarışma diğer bir tanımla rekabet kaçınılmazdır. Günümüz işletmecilik ortamında iç içe geçmiş farklı tarafların da bu durumdan etkilenmemesi imkansızdır. İşletmeler, çok farklı şekillerde faaliyetleri hakkında tüm ilgililere yanıltıcı bilgi sunmak, rakiplerinin unvanlarını kullanmak veya rakip firmanın ürünlerini taklit ederek/kötüleyerek haksız rekabete taraf olabilmektedir. Muhasebe mesleği açısından rekabet, mevcut rekabetin belirlenen ilkeler ve yasal düzenlemeler çerçevesinde, düzen ve şeffaflık içerisinde sürdürülmesidir. Haksız rekabet ise, iktisadi rekabetin iyi niyet kurallarına aykırı davranılması ya da iyi niyetin kötüye kullanılması ile bir tarafa aşırı fayda sağlamaya yönelik aldatıcı davranışlar içermesi durumudur. Bu sebeple haksız rekabet, hukuki ve ekonomik boyutları yanı sıra etik boyutu ile de sosyal bir olgu olarak değerlendirilmelidir. (Kısakürek \& Akarsu, 2016) $\mathrm{Bu}$ değerlendirme kapsamında meslek mensubundan beklenen, faaliyetlerini gerek etik standartlar gerekse kanun koyucunun hazırladığı yasal düzenlemelere meslek örgütlerinin denetiminde yürütmesidir.

Meslekte rekabetin etik kuralların dışına çıkılarak, yasayla belirlenmiş kurallara aykırı biçimde yapılması ise "haksız rekabet" fiiline olarak tanımlanmıştır. (IYYMMMO, 2017) Haksız rekabet, meslek mensuplarının birbirleriyle ve is, sahibi ile olan ilișkilerini etkileyen aldatıcı veya dürüstlük kurallarına aykırı her tür davranışını veya meslek faaliyetlerini ifade etmektedir. (Kurnaz, Altunal, \& Özbek, 2016) Muhasebe meslek mensuplarının kamu yararına uygun hareket etme ve kamu yararını gözetme amaçları göz önüne alındığnda sundukları hizmetlere özgü tüm özellikleri taşımaları gerekliliği kaçınılmazdır. (Uysal, Türker, \& Kurt, 2009) Haksız rekabet temel etik ilkelerden dürüstlük ilkesi ile üzerine bina edilen bir kavramdır. Bu sebeple meslek mensupları haksız rekabete sebep olabilecek fiillerden kaçınmalıdır.

Muhasebe, mesleki ikilimlerin sıklıkla yaşandığı bir meslek olarak karşımıza çıkmakta fakat birçok mesleki standart ile düzenlenmiş olması sebebiyle diğer mesleklerden ayrılmaktadır. Muhasebe Meslek Mensupları İçin Uluslararası Etik Kurallar El Kitabı - Uluslararası Bağımsızlık Standartları Dâhil, muhasebe meslek mensuplarının kamu yararı sorumluluklarını kabul ettiğine dair temel ilkelerini belirlemektedir. Dürüstlük, tarafsızlık, mesleki yeterlilik ve özen, gizlilik/sır saklama ve mesleğe uygun davranış olarak sınıflandırılan temel ilkeler bir muhasebe meslek mensubundan beklenen davranış standardını oluşturmaktadır. Söz konusu standartlar, muhasebe meslek mensuplarının temel ilkelere uyum ile ilgili tehditleri tanımlamak, değerlendirmek ve etkilerini azaltmak/ortadan kaldırmak için uygulayacakları kavramsal bir çerçeve sunmaktadır. (International Ethics Standards Board for Accountants, 2018) Anılan standartlar haksız rekabet ile doğrudan ilişkili olup, yerel mevzuatımızda olduğu şekliyle ayrı bir düzenlemeye gidilmemiştir. Bu durum söz konusu standartların ilke bazlı düzenlenmiş olmasından kaynaklanmaktadır.

Hızla değişen ekonomik ve sosyal koşullar, rekabetin her sektörde olduğu gibi muhasebe hizmetlerinde de belirleyici olmasında etken olmakta ve regülasyona tabi olmasını gerektirmektedir. Bu çerçevede ülkemizde muhasebe mesleğinde yaşanan rekabetin meslek mevzuatında yer alması; 21.11.2007 tarih ve 26707 sayılı Resmi Gazete'de yayınlanan "Serbest Muhasebecilik, Serbest Muhasebeci Mali Müs,avirlik ve Yeminli Mali Müșavirlik Mesleklerine İlişsin Haksız Rekabet ve Reklam Yasağ Yönetmeliğ" ile olmuştur. Başta TÜRMOB olmak üzere yönetmelikle oluşturulan TÜRHAK (Türkiye Haksız Rekabetle Mücadele Kurulu) ve tüm meslek odalarına önemli yetki ve görevler verilmiştir. Bununla birlikte kurul meslek mensuplarındaki haksız rekabet algısının geliştirilmesi için 2009 yılından günümüze bilgilendirme ve yayım faaliyetleri kapsamında 7 adet Haksız Rekabetle Mücadele Kongresi düzenlemiştir. Bu bağlamda mesleğin farklı faaliyet alanlarında haksız rekabetle mücadele konusunda tespit ve önerilerin sunulmasına zemin oluşturulmuştur.

Günümüzde de TÜRMOB tarafından bizzat hazırlanan ve uygulamaya başlatılmıs, olan E-Birlik projesi ile meslek örgütü, meslek odaları ve meslek mensupları arasında gerçekleşecek tüm is, ve işlemlerin elektronik olarak yürütülmesi Haksız Rekabetle Mücadele Yazılımı Programı ile sağlanacaktır. Haksız rekabetle mücadele çalışması ile hedeflenen, haksız rekabete maruz kalan tarafların, olası olumsuz etkilerden tüm dolaylı ilgililer dahil olmak üzere korunmasıdır. (Kurnaz, Altunal, \& Özbek, 2016) Bu yazılım sayesinde ücret almadan hizmete devam edilmesi, mükellef değişimi sırasında tahsilat sorunu, meslek tarifesi altında hizmet sunulması ve asgari ücretin doğru hesaplanmaması gibi başlıca sorunlar ile mücadele edilmeye çalışılmaktadır.

\section{LITERATÜR ARAŞTIRMASI}


Sayın ve Usman (2016) Yalova'da gerçekleştirdikleri çalışmalarında meslek mensuplarının meslek etiğine bakışlarını ve algılayış biçimlerini incelemiştir. Çalışmalarında muhasebe meslek mensuplarının büyük bölümünün mesleki ücret tarifesine uymamayı etik bir sorun olarak tanımladıklarını ancak bunu haksız rekabet olarak tanımlayan meslek mensubunun az olduğunu tespit etmiştir. Çalışmada mesleğe yeni başlayan meslek mensuplarının müşteri edinme sürecinde etik ikilemleri daha sık karşılaştıkları belirlenmiş,tir. Yeni müşteri edinme ya da mevcut müşteriyi elde tutma çabasındaki meslek mensuplarının etik dışı davranışları ise genelde meslegin dışında danışmanlık vb. ișler yapma taahhüdünde bulunmak suretiyle haksız rekabete yol açma ya da yalan beyanda bulunma șeklinde değerlendirilmiştir.

Aynı çalışmada muhasebe meslek mensuplarının birbirlerinin mesleki faaliyetlerini kötüleme gibi yollara başvurmadıkları ancak yeni müşteri edinme ya da mevcut müşteriyi devam ettirme çabasında olan meslek mensuplarının müşterisi ile defter tutma dışındaki faaliyetlerinde de yardımcı olabilme vaadi ile haksız rekabete sebep olabildikleri gözlenmiștir.

Muhasebe meslek mensupları arasında mesleki rekabetin yogun oldugu sıkça dile getirilmekle birlikte mükellef sayısı ile meslek mensupları karşılaştırıldığında oranın haksız rekabete sebep olacak düzeyde olmadığı görüşü de savunulmaktadır. Eger gerçekten rekabet var ise de bunun temel nedeni mesleki ve yasal düzenleme eksikliğnden kaynaklandığ açık bir gerçektir. Meslek mensuplarının defter tutma sayısına ilişkin bir sinırlamanın olmaması yapay olarak ifade edilen rekabetin olușmasında etken olabileceği ifade edilmektedir. (Ünsal, 2008)

Çukacı (2006)'nın meslek mensuplarının kamuyu aydınlatmadaki etik algılarını incelediği çalışmasında, İzmir ilinde çalışmasına katılan meslek mensuplarına; "Muhasebe etiğ denildiğnde aklınıza gelen kavramları sıralayınız" s,eklindeki ifadesine gelen cevaplar tekrarlanma sıklığına göre:

Dürüst olmak, sosyal sorumluluk sahibi olmak, mesleki sorumluluk, güvenirlilik, açıklık, șeffaflık, objektif davranmak, tarafsızlık, kişilik, önemlilik, kararlılık, mesleki borcunu ödemek, sözünde durmak, meslek ahlakını ve onurunu zedeleyici davranıs,ta bulunmamak, düșük ücret karşılığnda hizmetin kalitesini düs,ürmemek, meslek mensubu kişilerle rekabete girişmemek, meslek odasının almıs, oldugu kararlar ölçüsünde oda tüzügüne aykırı harekette bulunmamak, meslek mensubu mükellef diyalogu içerisinde seviyenin korunmasına dikkat etmek, devletin gelir kaynaklarına katkıda bulunmak, kişisel gelişş, saygılı olmak, saygınlık, gizlilik, mesleki ilke, mesleki dayanışma, karş̧lıklı saygı, kaydetme, belgeye dayanma, netlik, tutarlılık, ahlak, eșitlik, kararlılık, analiz, güven, diyalog içinde olmak, iletiş̧m, uyumluluk, bilgi paylaşımı, haksız rekabetin önlenmesi, kesin bilmediğiniz hakkında bir șey söylemek, gerçekçilik, mesleki eğtim, bilgi yenileme, meslek prensipleri, insan ilişkileri, mesleki egitim ve doğruluk șeklinde olmuştur.

Her ne kadar sıralamada haksız rekabet ve önlenmesi sonlara doğru yer alsa da bu fiilin ve etkilerinin sıralamada daha önce yer alan ve temel etik ilkelerle örtüşen durumlardan tamamen ayırt edilemeyeceği göz ardı edilmemelidir.

Biyan (2012) çalışmasında; meslek mensuplarının günlük işlerini tamamlayabilmek için, normal çalışma saatlerinden çok daha fazla çalışmak zorunda kaldıklarını, nitelikli personel bulmada zorluk yaşadıklarını, tahsilat sorunu ve meslek mensupları arasında haksız rekabet yașandığnı, kanun, tüzük ve yönetmelik gibi yasal düzenlemelerin anlaşılır olmaktan uzak oldugunu, ve TÜRMOB'un haklarını yeterince korumadıgını düs,ündügünü belirlemiștir. Meslek mensuplarının mesleki sorunlarının ortaya konulması amacıyla yapılan çalışmaya göre; meslek mensupları mesleki faaliyetlerde haksız rekabet sıklıkla yaşanmaktadır. Meslek mensuplarının \%98'i mesleklerinde haksız rekabet oldugunu düs,ünmekte ve buna paralel olarak da \%41,8'i mesleklerini sürdürülebilir olarak değerlendirirken, $\% 52,8^{\prime}$ i sürdürülebilir olarak değerlendirmemektedir.

Diğer bir çalışmada bağımsız çalışan meslek mensuplarının \%74,92'si yeni büro açan meslek mensuplarının mesleki ücret tarifesine uymamalarının haksız rekabete yol açması nedeniyle kendilerini kaygılandırdığnı vurgulamıştır. (Aydemir, 2015)

Benzer sonuçları olan çalışmalarında, Ömürbek ve Türkoglu (2013) haksız rekabete neden olan faktörleri mesleki deneyim süresine göre belirlemeye çalışmış, haksız rekabetin önemli boyutta oldugunu ve bu durumun başta tahsilat sorunu olmak üzere ücret üzerinden yaşanan haksız rekabetin meslek mensupları ekonomik ve sosyal açıdan olumsuz etkilediğni tespit etmiştir. Çalışmanın önemli bir diğer sonucu da haksız rekabetin meslek mensubunun toplumdaki algı ve itibarını zedelediği şeklindedir. 
Aydemir (2015)'e muhasebe meslek mensuplarının sorunları ve çözümüne yönelik beklentileri araştırdığı çalışmasında, meslek mensuplarının çogunlukla tahsilat problemlerinden, yogun is, yükünden, mevzuattaki güncellemelerden, sorumluluklarının fazlalığından, meslek mensubu sayısındaki artıştan, haksız rekabetten ve yeterli saygıyı görememekten vb. ş̧ikayet ettiklerini tespit etmiştir.

Uzay ve Güngör (2004)'ün Kayseri ve Nevş,hir'de gerçekleștirdiği çalışmada meslek mensuplarının başlıca sorunlarının tahsilat, geleceğe dair güvensizlik, haksız rekabet, yogun is, yükü ve mevzuattaki sık değişimler oldugu belirlenmiștir.

Kalaycı ve Tekșen'in (2006) Isparta'da yaptıkları çalışmada meslek mensuplarının sorunlarına ilişkin başlıca tespitleri şunlardır: En az vergi ödeten muhasebeci en iyi muhasebeci olarak görülmektedir. Sürekli degiss,en mevzuat yüzünden güncel uygulamaların takibi zorlaşmaktadır. Meslek mensupları arasında haksız rekabet bulunmaktadır, is, yükü çok fazladır ve hak ettiklerinden daha az ücret almaktadır.

Tetik, Kınay ve Ciğr (2008), Antalya'da faaliyet gösteren 121 muhasebe meslek mensubunun katılımıla gerçekleştirdikleri çalışmalarında; meslek mensuplarının karşılaştıkları sorunları başta tahsilat sıkıntıları, nitelikli personel tedarikinde yaşanan zorluklar ve haksız rekabet biçiminde sıralamıştır.

Deran, Erduru ve Keleş (2016) yaptıkları çalışmada meslek odalarından haksız rekabetin tespiti ve haksız rekabeti önleyici çalışmalara yönelik beklentilerin demografik özellikler ve faaliyette bulunulan ekonomik çevreden etkilendiğini ifade etmiştir.

Yıldız (2010) Kayseri'de gerçekleştirdiği çalışmasında SMMM'lerin meslek etiği algılamalarını ve meslek mensuplarının etik dışı uygulamalara yönelten ifadeleri belirlemeye yönelik bir alan çalışma yapmıştır. Çalışmada meslek örgütünün haksız rekabeti engellemekte yetersiz kaldığnı, etik dışı davranışlarda bulunanların meslekten dışlayamadığnı, meslek mensuplarını etik ilkelere zorlamakta meslek örgütünün gücü ve otoritesini yeterli bulmadıklarını ve meslek örgütü tarafından olușturulan meslek etigi ilkelerini yetersiz bulduklarını tespit etmiştir.

Ergün ve Gül (2005) Balıkesir il merkezinde bulunan meslek mensuplarının meslek etiği kuralları ile ilgili bilgi, düşünce ve algılamalarını ortaya çıkarmaya yönelik yaptıkları araştırmada meslek mensuplarının haksız rekabet yapmamak konusundaki düşüncelerinin en yüksek oranda meslektaşları ile iş almada ücret konusunda rekabet etmemek şeklinde sinıflandırmıştır.

Kurnaz, Altunal ve Özbek (2016) çalışmalarında haksız rekabetin en önemli unsurlarından biri olan ücret rekabetinin en aza indirilmesi için planlanan E-Birlik uygulamasından memnuniyeti araştırmıştır. "E-Birlik uygulamalarının kullanımı ücretsiz olarak sürdürülmelidir" ve "E-Birlik uygulaması sayesinde sözleşmelerimizi elektronik ortamda düzenleyerek, işlerimizi kolaylaștırdı" ifadesinin de yüksek düzeyde ortalamaya sahip oldugu ve bu ifadeden meslek mensuplarının is, yükünü azalttığnı, ișlerinde kolaylık sagladığ anlaşılmıst,ır. "E-birlik uygulaması sayesinde parasını alamadığm müstterilerimden tahsilat yapmaya bașladım" sorusunun ortalaması ise düşük çıkmış,ır.

\section{Araştırmanın Yöntemi}

Bu bölümde çalışma kapsamında yürütülen analizlere yer verilmiştir. Çalışma evreninin tespitinde olasılığa dayalı olmayan yargısal (kasıtlı/iradi) örneklem metodu kullanılmıştır. Söz konusu çalışma evreni, doktora unvanına sahip muhasebe meslek mensuplarından oluşmaktadır. SMMM ve YMM unvanları ile faaliyet gösteren ya da göstermiş olan meslek mensuplarından doktora derecesine sahip olanlar örnekleme alınmıştır. İlgili evreninin büyüklüğü (tüm muhasebe meslek mensupları) göz önünde bulundurulduğunda, böyle bir kısıtlama gerekli hale gelmiştir. Analitik Hiyerarşi Süreci (AHP) metodunda, diğer analiz yöntemlerinden farklı olarak örneklemin evreni temsil edeceği bir formülasyon geliştirilmemiştir. Çünkü AHP'nin ulaşmak istediği sonuç, konu ile ilgili birinci dereceden uygulayıcıların/karar vericilerin beyanlarına ulaşılması ve bu noktada en doğru bilgilerin elde edilmesi şeklindedir. Dolayısıyla AHP metodu bir örneklem endişesi taşımaz. Çalışma özelinde 17 doktoralı meslek mensubuna ulaşılmış ve bu 17 kişiden toplam 153 AHP matrisi elde edilmiştir. Bununla birlikte her bir katılımcıdan 17 kriter matrisi elde edilmiştir. Bu yolla ilgili çalışma 170 matrisin analize dâhil edilmesiyle başlamıştır. Fakat 170 matristen 146 AHP matrisinin ve 16 kriter matrisinin tutarlı olduğu tespit edilmiştir. Sonuç olarak 162 tutarlı matris analize konu edilerek çalışma nihayete kavuşmuştur. . 
Çalışmanın temel amacı, muhasebe meslek mensuplarının haksız rekabet algılarının ölçülmesidir. Bu noktada derecelendirilen temel alternatifler Türkiye Serbest Muhasebeci Mali Müşavirler ve Yeminli Mali Müşavirler Odaları Birliği'nin yayınladığı, Serbest Muhasebecilik, Serbest Muhasebeci Mali Müşavirlik ve Yeminli Mali Müşavirlik Mesleklerine İlişkin Haksız Rekabet ve Reklam Yasağı Yönetmeliği dikkate alınarak hazırlanmıştır. Bununla birlikte yapılan mülakatlar ve görüşmeler sonucunda elde edilen haksız rekabet çeşitleri de alternatifler arasına alınmış ve modele dâhil edilmiştir.

Çalışmada araştırma yöntemi olarak Analitik Hiyerarşi Süreci (AHP) kullanılmıştır. AHP modeli, alternatif arasında derecelendirme yaparken, çok sayıda karar vericinin bulunduğu, çok kriterli karar verme durumunda kullanılır. Bu aşamada başarılı ve gerçekçi sonuçlara ulaşılabilmesi için konularında uzman ve bilgili kişilerin tercih edilmesi oldukça önemlidir. AHP yöntemi çerçevesinde seçilen karar alıcıların ana kütleyi temsil etmesi yerine söz konusu karar alıcıların üzerinde çalışılan alanda tümüyle uzman olmaları aranmaktadır (Arslan, 2020). Bu yöntem için belirlenen standart puanlama yöntemi sayesinde veriler matrislere işlenmekte ve analizin yapılacağı veri setleri elde edilmektedir. Söz konusu puanlama değerleri ve karşılık gelen tanımları şu şekildedir;

Tablo 1: AHP Puanlama Değerleri

\begin{tabular}{|c|c|}
\hline Önem Değerleri & Değer Tanımları \\
\hline 1 & Eşit Önemde \\
\hline 3 & Biraz Daha Önemli (Az Üstünlük) \\
\hline 5 & Oldukça Önemli (Fazla Üstünlük) \\
\hline 7 & Çok Önemli (Çok Üstünlük) \\
\hline 9 & Son Derece Önemli (Kesin Üstünlük) \\
\hline $2,4,6$ ve 8 & Ara Değerler (Uzlaşma Değerleri) \\
\hline
\end{tabular}

Kaynak: (Satty: 1980)

AHP; 1970'li yıllardan bu yana karar vericiler ve araştırmacıların en çok kullandığı çok kriterli karar verme modeli olarak karşımıza çıkmaktadır. Planlama, en iyi alternatifi seçme, kaynakların etkili ve verimli kullanımı, optimizasyon (benzetim) vb. gibi birçok araştırma ve uygulamalarda AHP modeli tercih edilmektedir (Vaidya ve Kumar, 2006: 2).

Yöntemi geliştiren Saaty'e göre metot aşağıdaki temel aşamadan oluşur (Satty, 204: 9);

$>$ Hiyerarşi modelinin oluşturulması

> Tercih (İkili karşılaştırma) Matrisleri oluşturulması

$>$ Üstünlüklerin belirlenmesi

$>$ Bütünleştirme (sentez)

AHP yönteminin uygulamada sağladığı bazı faydalar (Vaidya ve Kumar, 2006);

> Bir hiyerarşi kurularak karar problemleri biçimsel olarak ifade edilebilir. Böylece, karmaşık problemler bileşenlerine ayrılarak karışıklıkları daha basit bir yapıya kavuşturulur,

> Alternatiflerin ikili karşılaştırmaları sırasında karar vericinin kişisel hükümleri kullanılır. Böylece karar verme sürecinde sadece sayısal verilere dayalı çözüm aranmaz, kişisel fikir ve düşünceler de dikkate alınır,

> Karar verici ikili karşılaştırmaları yaparak problemin her bir parçasına daha fazla yoğunlaşabilir. Bu esnada sadece iki elemanın düşünülmesi nedeniyle yapılacak değerlendirmeler basitleşmektedir. Diğer yandan değerlendirmeler sayısal olarak ifade edilemiyorsa, sözel ifadelerin kullanılması da mümkündür,

> Karar verici, hem objektif hem de sübjektif faktörleri bir arada dikkate alarak alternatifleri değerlendirebilir, 
G. Karakaya - A. A. Biçer 12/2 (2020) 1149-1158

> Karar vericinin yaptığı ikili karşılaştırmaların tutarlılığını test etmek mümkündür. Böylece karar verici, tutarsızlık durumunda verdiği hükümleri tekrar ele alarak düzeltme imkânına sahiptir.

Çalışmada 9 farklı haksız rekabet türü/alternatifi tespit edilmiş ve analize tabi tutulmuştur. Söz konusu alternatifler;

$>$ Muhasebe ve denetim standartlarına uymamak,

> Meslek faaliyetlerinde mesleki özen göstermemek,

$>$ İzinsiz faaliyette bulunmak,

$>$ Meslek ruhsatının kiralanması,

> Gerçeğe aykırı belge düzenlemek ve onaylamak,

> Mevzuat hükümlerine aykırı davranmak,

> Ücret ve diğer mali nitelikteki uygulamalar ile haksız rekabet,

$>$ Reklam yoluyla haksız rekabet,

> Mesleki ve akademik unvan dışında sahip olunan başka unvanları kullanmak

Bununla birlikte ilgili alternatifler derecelendirilirken 4 farklı kritere başvurulmuştur. Bunlar ise;

> Etik ve Ahlaki Illkelerin Zedelenmesi,

> Genel Kabul Görmüş Muhasebe İlkelerine Uyum,

> Dürüst ve bozulmamış rekabetin sağlanması,

> Mesleki kalite ve repütasyon

Analiz kısmında evrende yer alan ve konunun uzmanı olan kişilerin verdiği değerler matrislere işlenmiştir. İlgili kişi sayısınca doldurulan matrisler; tüm kriterler için, bütün haksız rekabet alternatifleri arasında yapılmıştır. Doldurulan tüm matrisler tutarlılık testlerine tabi tutularak her matris için ayrı ayrı tutarlılık oranlarına erişilmiştir. Çalışmanın güvenilirlik seviyesi bu yolla artırılmıştır. Her bir kriter bazında tüm kullanıcıların girmiş oldukları veriler için ayrı ayrı tatbik edilmiş ve tutarlı olup olmadıkları tespit edilmiştir. Bu yolla AHP Skorları elde edilmiştir. Bununla birlikte kriterlerin kendi aralarındaki derecelendirme sonuçları için yine tutarlılık testleri yapılmış ve kriter skorları elde edilmiştir. Her iki bileşen sayesinde meslek mensuplarının haksız rekabet algılarına ilişkin nihai sıralama elde edilmiştir.

\section{Bulgular}

Tespit edilen alternatiflerin ilgili kriterler dikkate alınarak analiz edilmesi, matrislerin oluşturulması ile başlamıştır. Ardından veri girişleri sağlanmış ve her bir matrisin simetrik değerleri alınıp tutarlılıkları tespit edilmiştir. Tutarlı olmayan matrisler modele dahil edilmemiştir. Aynı süreçler her bir kriter içinde yapılmıştır. Çalışma için hazırlanan AHP matrisi örneği şu şekildedir;

Tablo 2: AHP Matrisi 
Nihai Sonuç Alternatifler

\begin{tabular}{|c|c|c|}
\hline 0,18522 & Meslek faaliyetlerinde mesleki özen göstermemek & 0,22 \\
\hline 0,12563 & Ücret ve diğer mali nitelikteki uygulamalar ile haksız rekabet & 0,15 \\
\hline 0,10842 & Muhasebe ve denetim standartlarına uymamak & 0,13 \\
\hline 0,10143 & Meslek ruhsatının kiralanması & 0,12 \\
\hline 0,08301 & Reklam yoluyla haksız rekabet & 0,10 \\
\hline 0,07606 & Mevzuat hükümlerine aykırı davranmak & 0,09 \\
\hline 0,06427 & İzinsiz faaliyette bulunmak & 0,08 \\
\hline 0,05693 & Gerçeğe aykırı belge düzenlemek ve onaylamak & 0,07 \\
\hline 0,05547 & Mesleki ve akademik unvan dışında sahip olunan başka unvanları kullanmak & 0,06 \\
\hline
\end{tabular}

Sonuçların grafik gösterimi;

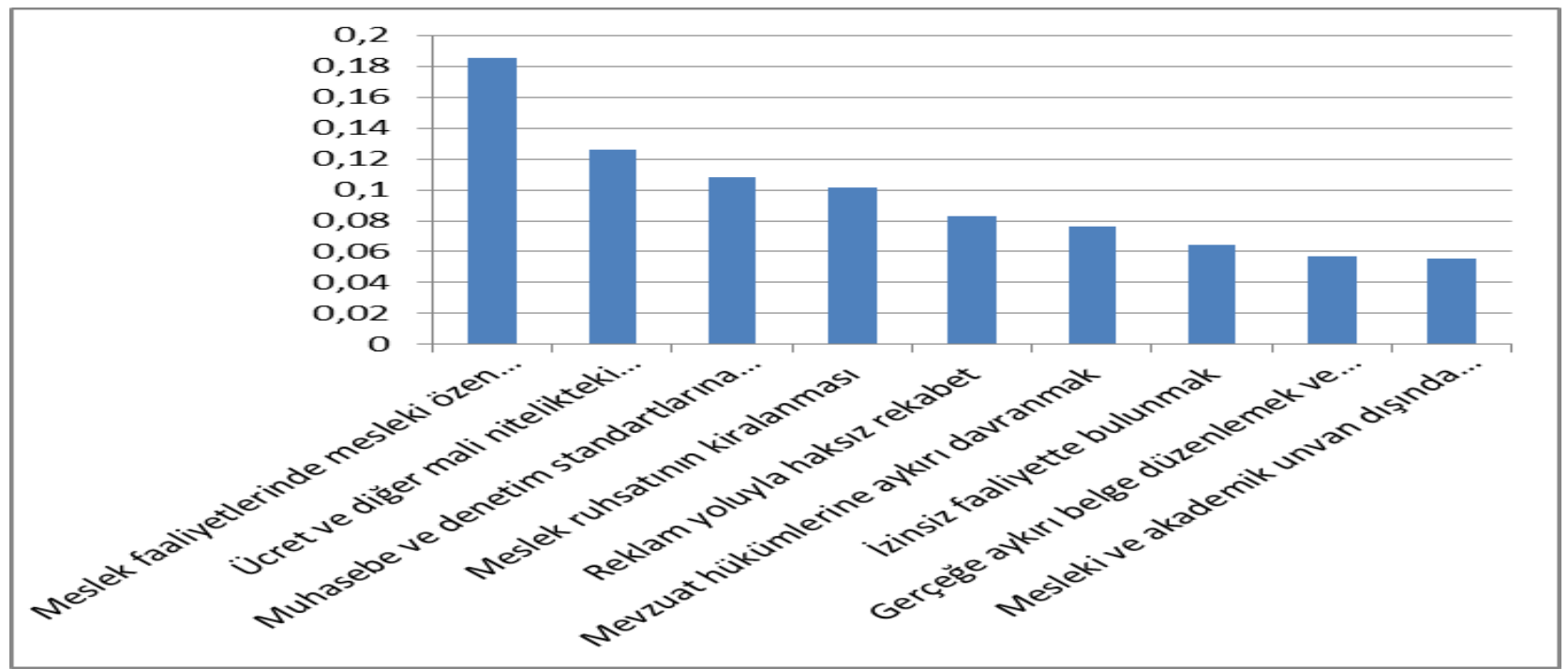

Grafik 1: Muhasebe Meslek Mensuplarının Haksız Rekabet Algıları - Grafik

\section{SONUÇ}

Etik kavramı son yıllarda gerek sosyal gerekse iş hayatında karşımıza sıklıkla çıkmakta olan bir kavramdır. İyi ile kötüyü, doğru ile yanlışı ayırt etme noktasında belirleyici bir disiplin olan etik, birçok meslek için söz konusu olmakla birlikte muhasebe meslek mensupları için uluslararası kriterler ile sınırlarının çizilmiş olması muhasebe mesleğini diğer mesleklerden ayrıştırmaktadır. Belirlenen uluslararası standartlara rağmen bu standartların ilke bazlı olmasından ötürü farklı meslek mensuplarının aynı durum ve olaylar için farklı etik değerlendirmeler yapması olağandır.

Bir takım ekonomik sebepler ya da beklentiler ile gerçekleştirilen haksız rekabet fiiller ile mesleğin hem kamuoyundaki itibari hem de meslek mensupları arasındaki profesyonel ilişkiler zedelenmektedir. Bu sebeple çalışma kapsamında gerçekleştirilen araştırma sonuçları şu şekildedir;

> Muhasebe meslek mensupları, haksız rekabete konu olan en önemli etkenin \%22'lik bir payla meslek faaliyetlerinde mesleki özen göstermemek olduğunu ifade etmiştir. Özellikle muhasebe meslek mensuplarının nicelik olarak giderek arttığı bu dönemde söz konusu haksız rekabet unsurunun ilk sırada yer almasının anlamlı olduğu düşünülmektedir. 
> Muhasebe meslek mensupları, haksız rekabete konu olan en önemli ikinci etkenin \%15'lik bir payla ücret ve diğer mali nitelikteki uygulamalar ile haksız rekabet olduğunu ifade etmiştir. Nicelik bakımından giderek artan meslek mensubu sayısının neden olacağı rekabet seviyesi ve türleri düşünüldüğünde söz konusu haksız rekabet unsurunun ikinci sırada yer almasının anlamlı olduğu düşünülmektedir.

$>$ Muhasebe meslek mensupları, haksız rekabete konu olan en önemli üçüncü etkenin \%13'lük bir payla muhasebe ve denetim standartlarına uymamak olduğunu ifade etmiştir. Muhasebe ve denetim standartlarına uygun bir meslek icrasının çoğu zaman göz ardı edildiği ya da ikinci plana atıldığı günümüz rekabet şartlarında bu konunun üzerinde daha da derinlemesine durulması gerektiği düşünülmektedir.

> Muhasebe meslek mensupları, haksız rekabete konu olan en önemli dördüncü etkenin \%12'lik bir payla meslek ruhsatının kiralanması olduğunu ifade etmiştir.

> Muhasebe meslek mensupları, haksız rekabete konu olan en önemli beşinci etkenin \%10'luk bir payla reklam yoluyla haksız rekabet olduğunu ifade etmiştir. Özellikle dijital çağın sunduğu çeşitli araçların bu noktada önemli bir etken olduğu fakat ilgili araçlara erişim ve kullanım düzeylerinin homojen olması nedeniyle ilgili unsurun haksız rekabete ilk sıralarda yer alabilecek ölçüde etki etmediği anlaşılmaktadır.

> Muhasebe meslek mensupları, haksız rekabete konu olan en önemli altıncı etkenin \%9'luk bir payla mevzuat hükümlerine aykırı davranmak olduğunu ifade etmiştir. Özellikle devlet otoritesinin tüm meslek mensuplarına yönelik ortak bir tutum sergilemesi nedeniyle, söz konusu haksız rekabet unsurunun çok önemli görülmediği anlaşılmaktadır.

$>$ Muhasebe meslek mensupları, haksız rekabete konu olan en önemli yedinci etkenin \% $8^{\prime}$ lik bir payla izinsiz faaliyette bulunmak olduğunu ifade etmiştir.

> Muhasebe meslek mensupları, haksız rekabete konu olan en önemli sekizinci etkenin \%7'lik bir payla gerçeğe aykırı belge düzenlemek ve onaylamak olduğunu ifade etmiştir. Özellikle denetim ve kontrol faaliyetlerinin bu denli geliştiği bir dönemde ilgili haksız rekabet unsuru en düşük önem seviyelerinde değerlendirilmiştir.

> Son olarak, muhasebe meslek mensupları, haksız rekabete konu olan en önemli dokuzuncu etkenin \% 6'llk bir payla mesleki ve akademik unvan dışında sahip olunan başka unvanları kullanmak olduğunu ifade etmiştir.

Çalışma, AHP yönteminin muhasebe meslek mensuplarının haksız rekabet algısının ölçülmesi yönünde yapılan ilk çalışma olup yapılacak sonraki çalışmalarda; muhasebe meslek mensuplarının mesleki ve/veya etik muhakeme becerilerinin haksız rekabet algisı üzerindeki etkisinin ortaya konulması durumunda düzenleyici kuruluşlar nezdinde haksız rekabete daha kesin çözümler üretebilecek yollar bulunabileceği düşünülmektedir. Uluslararası uygulamalara bakıldığında meslek mensuplarının etik yükümlülüklerine yönelik tek bir standart seti üzerinden değerlendirme yapıldığı görülmektedir. Ülkemizde muhasebe meslek mensuplarının haksız rekabet uygulamalarına ilişkin ilave düzenlemeler getirilmiş olması konunun önemine dikkat çekmektedir. Bu hususun çözümüne katkı sağlayabileceği düşünülen önlem/uygulamaların ortaya konulmadan önce meslek mensuplarının etik ve haksız rekabet fiillerine ilişkin algılarının ortaya konulması gerekmektedir. Aksi taktirde getirilecek yasal düzenlemelerin uygulamaya geçmesi ve tabana yayılması mümkün görülmemektedir. 


\section{G. Karakaya - A. A. Biçer 12/2 (2020) 1149-1158}

\section{Kaynakça}

Arslan, Ö. (2020). İşletmelerin Muhasebe Meslek Mensubu Seçimine Etki Eden Faktörlerin AHP Yöntemi. İşletme Araştırmaları Dergisi, 372-383.

Çukacı, Y. (2006). Kamuyu Aydınlatmada Muhasebe Meslek Elemanının Etik Anlayışı ve Izmir Ilinde Bir Uygulama. Dokuz Eylul Universitesi Sosyal Bilimler Enstitü̈üDergisi, 8(1), 89-111.

Ömürbek, V., \& Türkoğlu , T. (2013, Aralık). Muhasebe Meslek Mensupları Arasında Yaşanan Haksız Rekabet Użerine Bir Araştırma. Balıkesir Universitesi Sosyal Bilimler Enstitü̈üDergisi, 16(30), 115-149.

Aydemir, O. (2015, Temmuz). Muhasebe Meslek Mensuplarının Karş̧laștıkları Sorunlar Ve Beklentiler. Muhasebe ve Finansman Dergisi, 71-84.

Biyan, Ö. (2012). Muhasebe Meslek Mensuplarına Yönelik Bir C,alışma: Meslek Mensuplarının Demografik Durumları, Mesleki Sorunları ve Degerlendirilmesi. Sosyoekonomi(1).

Deran, A., Erduru, İ., \& Keleş, D. (2016, Ekim). Muhasebe Meslek Mensuplarının Mesleki Sorunlar ve Meslek Odalarından Beklentillerinin Demografik Özellikler ve Faaliyet Gösterilen Ekonomik Çevre Açısından Değerlendirilmesi: Ordu Örneği. Selçuk Üniversitesi İktisadi ve İdari Bilimler Fakultesi Sosyal Ekonomik Araştırmalar Dergisi (The Journal of Social Economic Research), Yil: 16(32), 84-109.

Ergün, H., \& Gül, K. (2005, Ocak). Muhasebe Mesleğ̊ Etik Kuralları ve Bu Kuralların Meslek Mensuplarınca Algılanıș. Muhasebe ve Finansman Dergisi(25).

Gündüz, M., \& Özen, E. (2016, Nisan). Muhasebe Meslek Mensuplarının Sorunları ve Mesleki Memnuniyetlerinin Analizi: Us,ak Ili Orneğ. Muhasebe ve Finansman Dergisi, 67-90.

Ünsal, A. (2008, Haziran 14). Işletmelerde Muhasebe Yöneticilerinin Etiksel Karar Süreci. KMU IIBF Dergisi, Yil: 10(14), 401-419.

International Ethics Standards Board for Accountants. (2018). Handbook of the International Code of Ethics for Professional Accountants _ including International Independence Standards (Cilt 2018 Edition). New York: International Federation of Accountants.

Kısakürek, M., \& Akarsu, A. (2016, Nisan). Muhasebecilik Mesleginde Haksız Rekabet Olgusu: Sivas Ilinde Bir Arast,trma. Atatü̈k Universitesi Sosyal Bilimler Enstitü̈̈̈Dergisi, 20(2), 647-664.

Kurnaz, N., Altunal, I., \& Özbek, A. (2016). Haksız Rekabeti Önleme Açısından TURMOB E-Birlik Yazılımı Hakkında Meslek Mensuplarının Değerlendirmeleri Uzzerine Ampirik Bir Çalışma. Mali Çözüm, 13-29.

Saaty, Thomas, (1980), The Analytic Hierarchy Process, Mc Graw - Hill, New York

Sayım, F., \& Usman, Ö. (2016). Muhasebe Meslek Mensuplarının Etik Algısı - Yalova Örneği- . Uluslararası Yö̈etim Iktisat ve Ișletme Dergisi, ICAFR 16 Ö̈el Sayısı, 247-261.

Tetik, N., Kınay, F., \& Ciğer Ayşegül. (2008). Antalya Ilindeki Muhasebe Meslek Mensuplarına Yönelik Durum Analizi ve Beklentilerini Saptamaya Yönelik Bir Araștırma. Muhasebe ve Finansman Dergisi(38), 70-79.

Uysal, T., Türker, M., \& Kurt, G. (2009). Etik ve Etik Kurallar Muhasebe Meslek Mensupları İcin . Ankara: T.C. Sayıştay Başkanlığı.

Uzay, Ş., \& Güngör, Ş. (2004). Muhasebecilerin Sorunları ve Beklentileri: Kayseri ve Nevșehir Illeri Uygulamas1. Muhasebe ve Finansman Dergisi(22), 1-13.

Vaidya, O. S., \& Kumar, S. (2006), Analytic Hierarchy Process: An Overview Of Applications. European Journal of operational research, 169(1), 1-29.

Yıldız, G. (2010). Muhasebe Mesleğinde Meslek Etiği ve Kayseri İl Merkezinde Bir Uygulama. Erciyes Üniversitesi Iktisadi ve İdari Bilimler Fakültesi Dergisi(36), 155-178. 